\title{
Saline Water, Pit Coating and Calcium Fertilization on Chlorophyll, Fluorescence, Gas Exchange and Production in Passion Fruit
}

\author{
Marlene A. F. Bezerra ${ }^{1}$, Lourival F. Cavalcante ${ }^{1}$, Francisco T. C. Bezerra ${ }^{1}$, Aldeir R. Silva ${ }^{2}$, \\ Flaviano F. Oliveira ${ }^{3} \&$ Sherly A. S. Medeiros ${ }^{1}$ \\ ${ }^{1}$ Postgraduate Program in Agronomy, Federal University of Paraíba, Paraiba States, Brazil \\ ${ }^{2}$ University of São Paulo, Luiz de Queiroz College of Agriculture, São Paulo States, Brazil \\ ${ }^{3}$ Postgraduate Program in Plant Science, Federal University of Viçosa, Minas Gerais States, Brazil \\ Correspondence: Marlene A. F. Bezerra, Postgraduate Program in Agronomy, Federal University of Paraíba, Areia \\ Municipally, Paraiba States, Brazil. Tel: 55-839-9814-7814. E-mail: marlene_agro@hotmail.com
}

Received: September 23, 2018

Accepted: November 6, 2018

Online Published: January 15, 2019

doi:10.5539/jas.v11n2p319

URL: https://doi.org/10.5539/jas.v11n2p319

\begin{abstract}
In plants sensitive to salinity, such as passion fruit, irrigation with saline water can cause physiological disturbances and reduce fruit production, necessitating the use of cultural practices that mitigate saline stress. The objective of this study was to evaluate the effects of water salinity, pit coating with high-strength polyethylene film, and calcium fertilization on the physiological and productive aspects of passion fruit 'BRS Gigante Amarelo'. The treatments were arranged in split plot in the scheme $2 \mathrm{WS} \times(2 \mathrm{LP} \times 5 \mathrm{DC})$, corresponding to water salinity $\left(0.3\right.$ and $\left.4.0 \mathrm{dS} \mathrm{m}^{-1}\right)$ as the main plot, side coating of pits (without and with) doses of calcium ( 0 ; $30 ; 60 ; 90$ and $120 \mathrm{~kg} \mathrm{ha}^{-1}$ ). During the flowering phase, we evaluated leaf chlorophyll indices, fluorescence kinetics, and gas exchange. The increase in calcium doses up to $60 \mathrm{~kg} \mathrm{ha}^{-1}$ increased leaf chlorophyll and quantum efficiency. The stomata did not restrict gas exchange, but salinity resulted in reduced net photosynthesis and plant production. The lateral coating of the pits intensified the reduction in salinity-promoted production, while calcium mitigated the effects of the salts. Entisol cultivated with passion fruit should not be irrigated with saline water of $4.0 \mathrm{dS} \mathrm{m}^{-1}$; lateral pit coating is not advised. In an Entisol with an initial calcium level of 1.92 $\mathrm{cmol}_{\mathrm{c}} \mathrm{dm}^{-3}$, the recommended application dose is $60 \mathrm{~kg} \mathrm{ha}^{-1}$ for passion fruit cultivation.
\end{abstract}

Keywords: Passiflora edulis Sims., reduction of water losses, physiology of passion fruit

\section{Introduction}

Yellow passion fruit (Passiflora edulis Sims.) is a tropical fruit and cultivated throughout Brazil, where it finds suitable soil and climatic conditions. According to Faleiro and Junqueira (2016), Brazil is the world's largest consumer of passion fruit; and also the largest producer, with 703,489,000 kg per year (IBGE, 2017). Among the Brazilian regions, passion fruit production is highest in the northeast, followed by the southeast, north, south, and mid-west, accounting for $70,14,8,6$, and $2 \%$, respectively, of the national production in 2016 but, in this region, the lowest productivity (13.320 kg per hectare) (IBGE, 2017).

The main limiting factor for agriculture in semi-arid (Brazilian northeast) and arid regions is water availability and quality, since water in these areas if often highly saline, with negative impacts on physiology, foliar chlorophyll, fluorescence, gas exchange, and, consequently, crop productivity (Freire, Dias, Cavalcante, Fernandes \& Lima Neto, 2014; Nunes et al., 2017; Sá et al., 2018). Stress, including saline stress, can be identified by changes in quantum kinetics (Roháček, 2002; Baker, 2008), limiting the flow of energy for $\mathrm{CO}_{2}$ assimilation. Salinity may reduce net photosynthesis due to stomatal closure (Freire et al., 2014) and/or interfere with the biochemical reactions in the chloroplasts (Sivakumar, Sharmila, \& Saradhi, 2000; Cruz, Coelho Filho, Coelho \& Santos, 2017). Passion fruit, considered sensitive to salinity, does not tolerate soil saturation extract conductivity levels higher than $1.3 \mathrm{dS} \mathrm{m}^{-1}$ (Ayers \& Westcot, 1999).

In arid and semi-arid areas, soil water losses can be reduced via side coating of pits with plastic film, maintaining soil moisture and mitigating the harmful effects of salts in irrigation water (Cavalcante et al., 2005). These authors claim that such an approach causes the dilution of salts in the root environment and, consequently, decreases the effect of osmotic stress and toxicity to plants, resulting in increased crop productivity under 
irrigation with high-salinity water. The reduction in water availability also interferes with physiological functions, resulting in losses in growth and production (Padilha et al., 2016).

Supplementation with calcium can also alleviate salt stress (Alla, Abogadallah, Badran, Nada, \& Hassan, 2014), because, in addition to functions in soil fertility and plant nutrition, calcium has important structural and metabolic functions; it stabilizes the cell wall, is a secondary messenger, and regulates enzymatic activities (Epstein \& Bloom, 2006; Eisenach \& Angeli, 2017). In addition, calcium interferes with the absorption of other ions (Epstein \& Bloom, 2006; Ortega \& Malavolta, 2012; Garrone, Campos, Silveira, \& Lavres Junior, 2016) by synergistic interaction with nitrogen (Ortega \& Malavolta, 2012; Cavalcante et al., 2014) and antagonistic interaction with magnesium (Fageria, Gheyi, \& Moreira, 2011; Salvador, Carvalho, \& Lucchesi, 2011; Ortega \& Malavolta, 2012).

In this context, the objective of this study was to evaluate the combined application of calcium and soil coating to passion fruit crops irrigated with saline water on the physiological and productive aspects of yellow passion fruit.

\section{Material and Methods}

The study was conducted between November 2015 and July 2016, on the site Macaquinhos $\left(7^{\circ} 0^{\prime} 8^{\prime \prime}\right.$ southern latitude, $35^{\circ} 47^{\prime} 58^{\prime \prime}$ western longitude of Greenwich, $564 \mathrm{~m}$ above sea level), municipality of Remígio, state of Paraíba, Brazil. According to the Köppen classification, the climate is As', tropical and with a distinct rainy season between March and August (Alvares, Stape, Sentelhas, Gonçalves, \& Sparovek, 2013).

The treatments were arranged in a split plot, $2 \times(2 \times 5)$ factorial design, with the main plot corresponding to the electrical conductivity of the irrigation water $\left(0.3\right.$ and $\left.4.0 \mathrm{dS} \mathrm{m}^{-1}\right)$ and the subplots representing coating of the pits against water loss and the different calcium doses $\left(0,30,60,90\right.$, and $\left.120 \mathrm{~kg} \mathrm{ha}^{-1}\right)$. The treatments were distributed in four randomized blocks; the experimental unit consisted of four plants.

The orchard was cultivated with the passion fruit cv. 'BRS Gigante Amarelo', with a planting density of 1,666 plants per hectare and a spacing of $2 \mathrm{~m}$ between rows and $3 \mathrm{~m}$ between plants within one row. In the treatments with lateral coating of the pits, was used high-strength plastic film $(320 \mu)$ at a distance of $50 \mathrm{~cm}$ from the center of the pit and at a depth of $45 \mathrm{~cm}$, aiming to reduce water losses by lateral infiltration. Seedling transplanting was performed in November 11, 2015; the plants were supported with simple trellises consisting of a flat wire $\left(\mathrm{n}^{\mathrm{O}}\right.$ 12), in stalled at a height of $2.2 \mathrm{~m}$ at the top of the piles.

The soil was a sandy Entisol, with the following properties in the 0-20-cm layer: $\mathrm{pH}$ in water, 4.58; calcium, magnesium, potassium, sodium, and potential acidity $\left(\mathrm{H}^{+}+\mathrm{Al}^{3+}\right), 1.92,0.48,0.08,0.05$, and $1.30 \mathrm{cmol}_{\mathrm{c}} \mathrm{dm}^{-3}$, respectively; phosphorus, $10.6 \mathrm{mg} \mathrm{dm}^{-3}$; organic matter, $5.1 \mathrm{~g} \mathrm{~kg}^{-1}$, electrical conductivity of the saturation extract, $0.82 \mathrm{dS} \mathrm{m}^{-1}$. Soil and particle density were 1.57 and $2.64 \mathrm{~g} \mathrm{~cm}^{-3}$, respectively, while sand, silt, total clay, and clay dispersed in water were $842,92,66$, and $13 \mathrm{~g} \mathrm{~kg}^{-1}$, respectively; flocculation was $80.3 \%$, with a total porosity of $0.41 \mathrm{~m}^{3} \mathrm{~m}^{-3}$.

Fertilization followed the recommendations of Borges and Souza (2010). The pits with the dimensions of $40 \times$ $40 \times 40 \mathrm{~cm}$ were treated with $20 \mathrm{~L}$ of tanned cattle manure, $15 \mathrm{~g}$ of N, $18 \mathrm{~g}$ of $\mathrm{K}_{2} \mathrm{O}, 12 \mathrm{~g}$ of $\mathrm{P}_{2} \mathrm{O}_{5}, 4 \mathrm{~g}$ of Zn, $2.7 \mathrm{~g}$ of $\mathrm{Mg}$, and $5.7 \mathrm{~g}$ of $\mathrm{S}$. In the growth phase, each plant was fertilized with $53 \mathrm{~g}$ of N, $65 \mathrm{~g}$ of $\mathrm{K}_{2} \mathrm{O}$, and $28 \mathrm{~g}$ of $\mathrm{P}_{2} \mathrm{O}_{5}$ in four monthly applications and one application with $18 \mathrm{~g}$ of magnesium sulphate. In the production phase, was supplied $72 \mathrm{~g}$ of $\mathrm{N}$ and $120 \mathrm{~g}$ of $\mathrm{K}_{2} \mathrm{O}$ in four monthly applications as well as $60 \mathrm{~g}$ of $\mathrm{P}_{2} \mathrm{O}_{5}$ in two installments, together with the first and third fertilization with nitrogen and potassium and $18 \mathrm{~g}$ of magnesium sulphate. The calcium doses were divided into five equal applications, the first in the preparation of the pits and the other four at $60,90,120$, and 150 days after seedling transplanting. The fertilizers used were urea $(45 \%$ de $\mathrm{N})$, calcium nitrate $(15.5 \% \mathrm{~N}$ and $19 \% \mathrm{Ca})$, potassium chloride $\left(60 \%\right.$ of $\left.\mathrm{K}_{2} \mathrm{O}\right)$, phosphate monoammonium $(11 \%$ $\mathrm{N}$ and $50 \% \mathrm{P}_{2} \mathrm{O}_{5}$ ), zinc sulfate $(20 \% \mathrm{Zn}$ and $9 \% \mathrm{~S})$, and magnesium sulfate $(9 \% \mathrm{Mg}$ and $13 \% \mathrm{~S})$.

Irrigation was based on crop evapotranspiration (ETc), calculated via the reference evapotranspiration product (ETo), crop coefficient in each phenophase $(\mathrm{Kc})$, and the coefficient of reduction $(\mathrm{Kr})$ of area $(\mathrm{ETc}=\mathrm{ETo} \times \mathrm{Kc} \times$ $\mathrm{Kr}$ ). Reference evapotranspiration was obtained by the product of the evaporation readings of the Tank Class 'A', installed near the site of the experiment, with a correction factor of 0.75 (Allen, Pereira, Raes, \& Smith, 2006). Cultivation coefficients were 0.43 in the vegetative phase, 0.94 at flowering, and 1.04 at fruiting. The reduction coefficient was based on the reduction of the wetting area of the localized irrigation (Steduto, Hsiao, Fereres, \& Raes, 2012).

For irrigation, four drippers were used per plant, with hydraulic head loss control, an individual flow of $10 \mathrm{~L} \mathrm{~h}^{-1}$, and a service pressure of $0.15 \mathrm{MPa}$. The non-salt water (electric conductivity-EC of $0.3 \mathrm{dS} \mathrm{m}^{-1}$ and sodium 
adsorption ratio of $\left.0.56\left(\mathrm{mmol} \mathrm{L}^{-1}\right)^{0.5}\right)$ was pumped from the surface, while the saline water $\left(\mathrm{EC}\right.$ of $\left.4.0 \mathrm{dS} \mathrm{m}^{-1}\right)$ was obtained by diluting non-iodinated $\mathrm{NaCl}$ in non-saline water in plastic boxes with a capacity of $3 \mathrm{~m}^{3}$. In the treatments with saline water, the water was added at $10 \%$ of the irrigation depth (Ayers \& Westcot, 1999).

In full bloom, during the first week of April in 2016, the third leaf in central branch was marked with a floral button for determination of physiological variables. In the distal, medial, and proximal parts at the base of the lobe of these leaves we measured the foliar indices chlorophyll ' $a$ ', chlorophyll ' $b$ ', chlorophyll 'b/a' ratio, and 'total' chlorophyll, using a portable clorofiLOG from FalKer ${ }^{\circledR}$. In the same sheet, after dark and adaptation by 30 'with clips, we measured initial fluorescence (Fo) and maximum fluorescence (Fm), using a model fluorometer OS-30p da Opti-Sciences ${ }^{\circledR}$. Based on these data, went calculated variable fluorescence (Fv) from chlorophyll 'a', quantum yields of non-photochemical processes (Fo/Fm) and photochemical processes (Fv/Fm) of photosystem II, and the relation between quantum yields of photochemical and non-photochemical competing products in photosystem II (Fv/Fo) (Roháček, 2002). Gaseous exchanges, stomatal conductance $\left(\mathrm{g}_{\mathrm{s}}, \mathrm{mol} \mathrm{m}^{-2} \mathrm{~s}^{-1}\right)$, stomatal resistance $\left(r_{s}=1 / g_{s}, \mathrm{~m}^{2} \mathrm{~s} \mathrm{~mol}^{-1}\right)$, relative stomatal limitation (ratio between internal and external concentration of carbon dioxide), internal concentration of carbon dioxide $\left(\mathrm{c}_{\mathrm{i}}, \mu \mathrm{mol}\right.$ of $\mathrm{CO}_{2} \mathrm{~mol}^{-1}$ of air), liquid assimilation of carbon dioxide $\left(\mathrm{A}, \mu \mathrm{mol} \mathrm{m} \mathrm{m}^{-2}\right)$, transpiration $\left(\mathrm{T}, \mathrm{mmol}\right.$ of $\left.\mathrm{H}_{2} \mathrm{O} \mathrm{m}^{-2} \mathrm{~s}^{-1}\right)$, water use efficiency $(\mathrm{EWU}=\mathrm{A} / \mathrm{T})$, instantaneous carboxylation efficiency $(\mathrm{iCE}=\mathrm{A} / \mathrm{Ci})$, and leaf temperature $\left(\mathrm{Temp},{ }^{\circ} \mathrm{C}\right)$ were determined with an infrared gas analyzer (IRGA), model LCpro-SD from BioScientific ${ }^{\circledR}$.

Harvesting was performed three times a week from April to July 2016; the fruits were harvested when the skin started to turn yellow, packed in plastic boxes, and fruit mass per plant was determined.

The data were submitted to analysis of variance. The effects of water and lateral protection of pits against water losses were verified by the F test $(\mathrm{p} \leq 0.05)$, the calcium doses were adjusted for regression with significance by the $F$ test $(p \leq 0.10)$, and the correlation between variables was analyzed. All data were analyzed using the software package SAS ${ }^{\circledR}$ University Edition and R-Studio ${ }^{\circledR}$.

\section{Results and Discussion}

Among the studied factors, calcium was the only one with a significant effect on leaf chlorophyll index ' $\mathrm{a}$ ' ( $\mathrm{F}=$ $3.17 ; \mathrm{p}=0.0206)$, chlorophyll ' $\mathrm{b}$ ' $(\mathrm{F}=2.86 ; \mathrm{p}=0.0317)$, and 'total' chlorophyll $(\mathrm{F}=3.11 ; \mathrm{p}=0.0226)$; the effect on chlorophyll ' $\mathrm{b} / \mathrm{a}$ ' ratio was not significant $(\mathrm{F}=2.17 ; \mathrm{p}=0.0844)$. With increasing calcium doses of up to 60 $\mathrm{kg} \mathrm{ha}^{-1}$, the highest values were obtained for chlorophyll 'a' (Figure 1A), chlorophyll 'b' (Figure 1B), chlorophyll 'b/a' ratio (Figure 1C), and 'total' chlorophyll (Figure 1D), with the respective maximum values of 33.0, 12.9, 0.39 , and 45.9 , representing increments of $4.5,10.3,5.4$, and $6.3 \%$ in relation to the treatment without calcium application. Since, in relative terms, the increase in calcium doses interfered with greater intensity in the synthesis of chlorophyll ' $b$ '. 
(A)
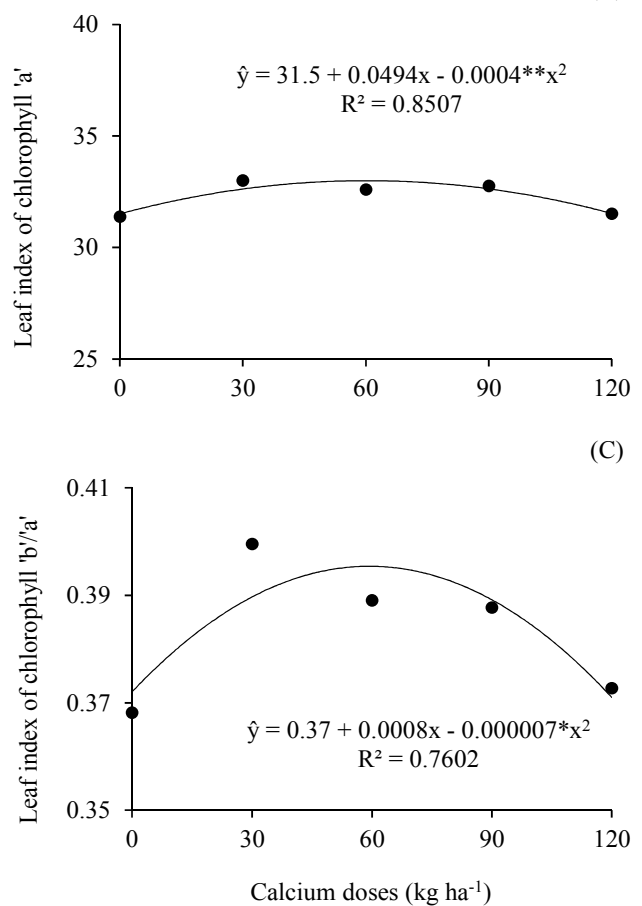

(B)

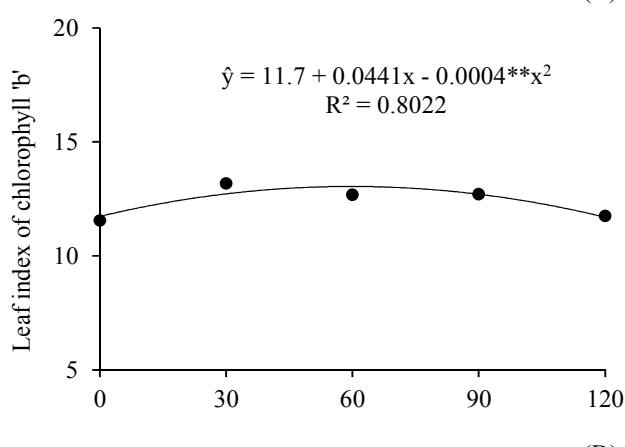

(D)

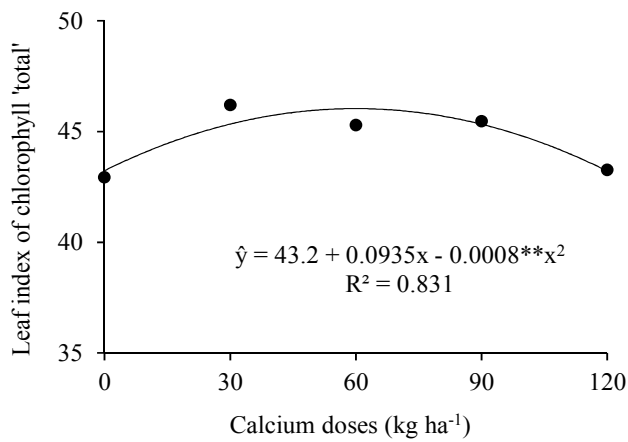

Figure 1. Values of chlorophyll 'a' (A), chlorophyll 'b' (B), chlorophyll 'b/a' ratio (C), and 'total' chlorophyll (D) for yellow passion fruit leaves (Passiflora edulis) as a function of calcium doses. * and **: significant at 5 and $1 \%$ probability, respectively

Calcium, although not a part of chlorophyll molecules (Blankenship, 2014), has an important role in the ionic absorption of plants (Epstein \& Bloom, 2006; El Habbasha \& Ibrahim, 2015). According to Ortega and Malavolta (2012), this macronutrient may exert a synergistic effect with nitrogen, possibly contributing to increasing chlorophyll synthesis. This finding is in agreement with Cavalcante et al. (2014), who noticed increased leaf nitrogen contents in passion fruit treated with different calcium doses. The observed reduction in chlorophyll production at calcium doses beyond $60 \mathrm{~kg} \mathrm{ha}^{-1}$ may be related to competition with magnesium (Salvador et al. 2011). Calcium can have an antagonistic effect (Fageria et al., 2011; Garrone et al., 2016), and magnesium is a structural nutrient of the chlorophyll molecules ' $a$ ' and ' $b$ ' (Epstein \& Bloom, 2006; Blankenship, 2014). Garrone et al. (2016), in a study on jatropha, observed that increased calcium concentrations in the nutrient solution reduced foliar magnesium, while Salvador et al. (2011) concluded that a calcium: magnesium ratio of $3: 1$ in the soil solution is suitable for soybean.

Initial fluorescence $(F o)$, variable fluorescence $(F v)$, and maximum fluorescence $(F m)$, chlorophyll ' $a$ ', the quantum yield of non-photochemical $(\mathrm{Fo} / \mathrm{Fm})$ and photochemical $(\mathrm{Fv} / \mathrm{Fm})$ processes of photosystem II, and the ratio between quantum yields of photochemical and non-photochemical processes in photosystem II ( $\mathrm{Fv} / \mathrm{Fo})$ were not impacted by the electrical conductivity of the irrigation water, pit coating, and calcium application, with respective mean values of 78.5, 289.8, 368.3, 0.21, 0.79, and 3.7. However, calcium increases of up to $70 \mathrm{~kg} \mathrm{ha}^{-1}$ reduced the quantum yield of non-photochemical processes from 0.23 to 0.21 (Figure 2A) and increased the photochemical processes of photosystem II from 0.77 to 0.79 (Figure 2B), while the ratio between quantum yields of photochemical and non-photochemical processes in photosystem II was increased from 3.4 to 3.9 (Figure 2C). 
(A)
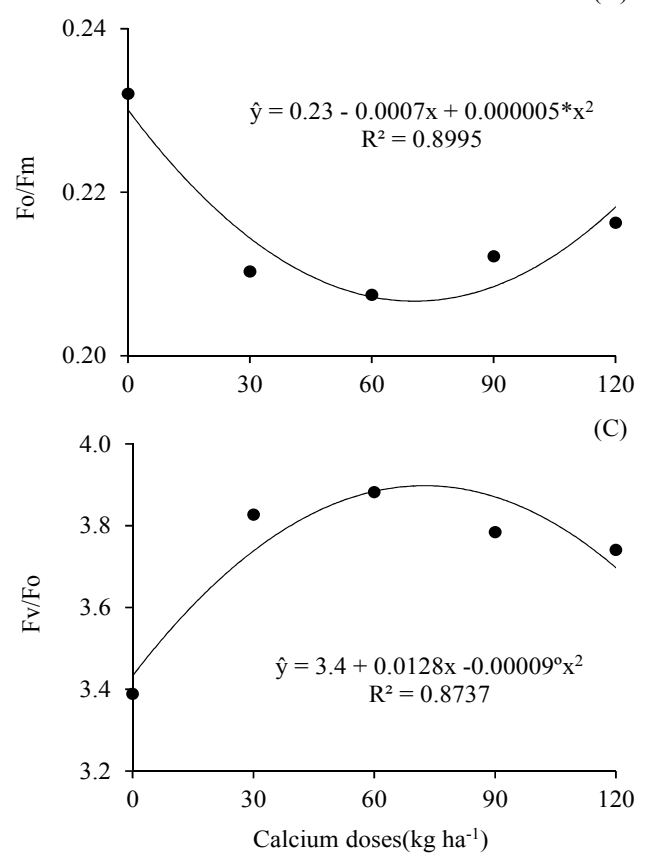

(B)

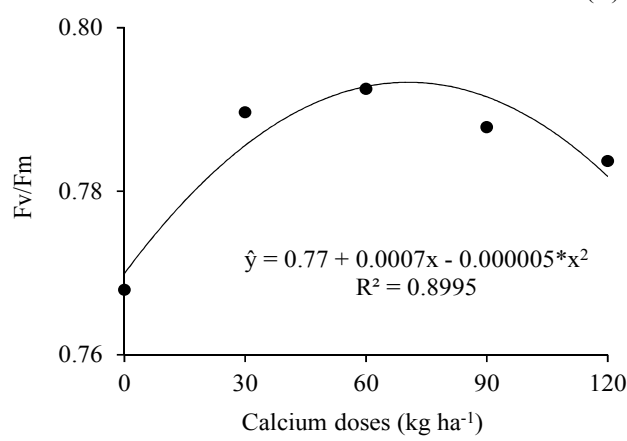

Figure 2. Quantum yield of non-photochemical (A) and photochemical (B) processes of photosystem II and ratio between quantum yields of photochemical and non-photochemical processes in photosystem II (C) on yellow passion fruit leaves (Passiflora edulis) as a function of calcium doses. ${ }^{\circ}$ and $*$ : significant at 10 and $5 \%$ probability, respectively

The increase in initial fluorescence (Fo), the reduction in maximum fluorescence (Fm) of chlorophyll ' $a$ ', and, mainly, the reduction of the quantum efficiency of photosystem II (Fv/Fm) indicate stress (Baker, 2008). The quantum yield of non-photochemical processes $(\mathrm{Fo} / \mathrm{Fm})$ and the proportion between quantum yields of photochemical and non-photochemical processes (Fv/Fo) are also indicators of stress situations (Roháček, 2002).

According to Roháček (2002), Fo/Fm values between 0.14 and $0.20, \mathrm{Fv} / \mathrm{Fm}$ values from $0.80-0.86$, and Fv/Fo values from 4-6 indicate that the plants are not stressed. Thus, in our study, the passion fruit plants were subjected to stress, which intensified with calcium doses below or above $70 \mathrm{~kg} \mathrm{ha}^{-1}$. Calcium, as a macronutrient, is essential for the integrity of the plasma membrane (Epstein \& Bloom, 2006), but in excess, it reduces the absorption of magnesium (Garrone et al., 2016; Guo, Nazim, Liang, \& Yang, 2016), a constituent of chlorophyll molecules (Epstein \& Bloom, 2006; Blankenship, 2014). It is therefore crucial to maintain an adequate calcium to magnesium ratio (Salvador et al., 2011) for don't alter the chlorophyll synthesis that is related to the photochemical processes of passion fruit (Figure 3). 


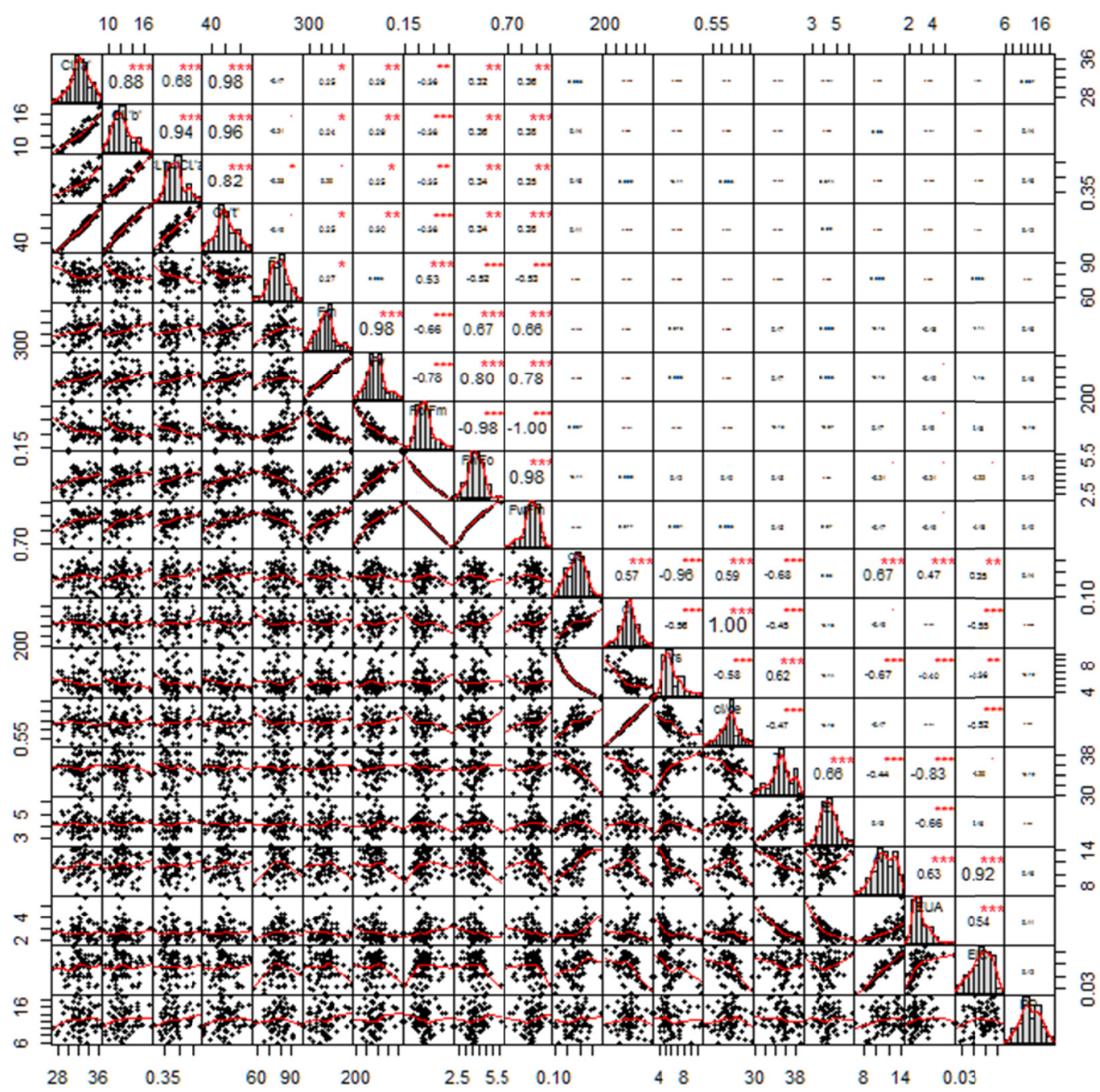

Figure 3. Pearson's correlation ( $\rho$ ) between chlorophyll indices, photochemical processes, and gas exchange of leaves of yellow passion fruit (Passiflora edulis) in full bloom. *, ** and ***: significant at 5,1 , and $0.1 \%$ probability, respectively

In terms of gas exchange, the interaction between coating of the pits and calcium doses affected the conductance $(\mathrm{F}=3.95 ; \mathrm{p}=0.0070)$ and stomatal resistance $(\mathrm{F}=3.89 ; \mathrm{p}=0.0076)$, as well as the relative stomatal limitation $(\mathrm{F}=2.90 ; \mathrm{p}=0.0304)$ and the internal concentration of carbon dioxide $(\mathrm{F}=2.85 ; \mathrm{p}=0.0326)$. Stomatal conductance, at doses of 30,90 , and $120 \mathrm{~kg} \mathrm{ha}^{-1}$ of calcium, was higher in plants grown in holes without side coating; however, in this situation, no functional relationship was established between calcium doses and electrical conductance, with an overall average value of $0.18 \mathrm{~mol} \mathrm{~m}^{-2} \mathrm{~s}^{-1}$ (Figure 4A). In contrast, in laterally coated pits, stomatal conductance increased up to $0.19 \mathrm{~mol} \mathrm{~m}^{-2} \mathrm{~s}^{-1}$ under a calcium dose of $50 \mathrm{~kg} \mathrm{ha}^{-1}$, representing an increase of $12 \%$ compared to the treatment without calcium addition. 

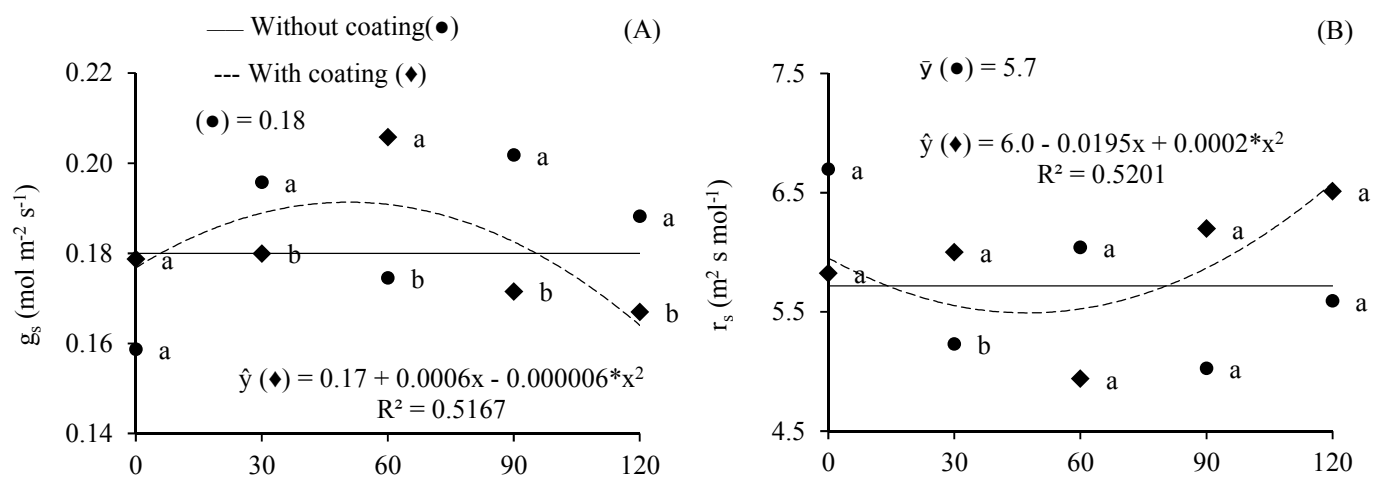

(C)
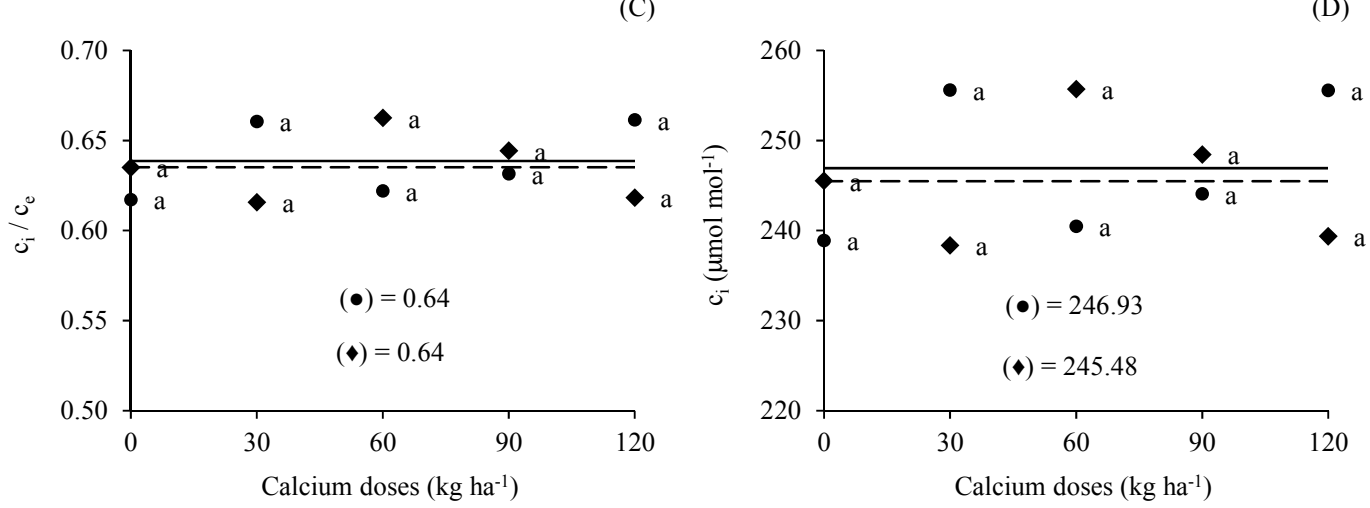

Figure 4. Stomatal conductance (A) and resistance (B), relation between internal and environmental carbon (C), and internal carbon dioxide concentration (D) of leaves of yellow passion fruit (Passiflora edulis) in full bloom, grown in pits without $(\bullet)$ and with $(\bullet)$ plastic coating, as a function of calcium doses. *: significant at $5 \%$ probability. Averages followed by the same letter do not significantly differ ( $F$ test; $p \leq 0.05$ )

Generally, stomatal resistance was inverse to electrical conductance. It was lower in plants grown in holes without side coating, but only at calcium doses below $30 \mathrm{~kg} \mathrm{ha}^{-1}$; in this situation, there was no functional relationship between calcium and resistance, with an average value of $5.7 \mathrm{~m}^{2} \mathrm{~s} \mathrm{~mol}^{-1}$ (Figure 4B). However, in the pits protected against water leakage by horizontal infiltration, increasing calcium doses from 0 to $49 \mathrm{~kg} \mathrm{ha}^{-1}$ reduced stomatal leaf resistance from 6.0 to $5.4 \mathrm{~m}^{2} \mathrm{~s} \mathrm{~mol}^{-1}$.

The smaller opening of the stomata, characterized by reduced conductance or increased stomatal resistance, of passion fruit in lined pits was probably a result of higher soil moisture over larger periods of time (Cavalcante et al., 2005). Padilha et al. (2016), working with jatropha, observed greater stomatal conductance in soil with $80 \%$ of water retention capacity, and values below or above this (up to $100 \%$ ) caused a decrease in conductance. However, the conservation of moisture caused by pit coating (Cavalcante et al., 2005) may have increased the availability of calcium to increase stomatal opening; since it acts as a secondary messenger (Epstein \& Bloom, 2006; Reyes, Alvarez-Herrera, \& Fernández., 2013; Eisenach \& Angeli, 2017). Furtado, Pereira, Andrade, Pereira Filho, and Silva (2012) observed that increase in the doses of calcium nitrate were reflected in greater stomatal conductance in watermelon.

For the relative stomatal limitation (Figure 4C) and internal $\mathrm{CO}_{2}$ concentration (Figure 4D), regardless of the calcium dose, no difference was observed in plants grown in pits without and with lateral coating. As well as the adjustments of the data to the doses of calcium were not significant. In C3 plants, such as yellow passion fruit, the ratio between internal and external carbon dioxide concentration should be between 0.6 and 0.8 (Berry \& Bownton, 1982); decreasing values are reflected in an increased stomatal limitation. In our study, this relation was $0.65 \pm 0.05$, indicating that photosynthesis was not limited and that the internal $\mathrm{CO}_{2}$ concentration $(246 \pm 19$ $\mu \mathrm{mol} \mathrm{mol}^{-1}$ ) was above the point of compensation $\left(50\right.$ and $\left.100 \mu \mathrm{mol} \mathrm{mol}^{-1}\right)$ for $\mathrm{C} 3$ plants (Taiz, Zeiger, Møller, \& Murphy, 2017).

Transpiration and leaf temperature of yellow passion fruit were not affected by any of the studied factors, with average values of $4.20 \mathrm{mmol} \mathrm{m} \mathrm{s}^{-1}$ and $35.4{ }^{\circ} \mathrm{C}$, respectively. However, in terms of net assimilation of carbon gas $(\mathrm{F}=5.23 ; \mathrm{p}=0.0261)$, instantaneous carboxylation efficiency $(\mathrm{F}=5.96 ; \mathrm{p}=0.0179)$, and water use 
efficiency $(\mathrm{F}=8.24 ; \mathrm{p}=0.0058)$, the interaction between water salinity and pit coating against horizontal infiltration was significant. For the carboxylation efficiency, pit coating and calcium addition $(F=2.89 ; p=$ 0.0305 ) also had a significant effect. The net assimilation of $\mathrm{CO}_{2}$ and the instantaneous carboxylation efficiency of passion fruit were not altered by lateral pit coating, but in the treatments with side coating, a salinity increase of 0.3 from $4.0 \mathrm{dS} \mathrm{m}^{-1}$ reduced net photosynthesis by $10 \%$ (Figure $5 \mathrm{~A}$ ) and net assimilation of $\mathrm{CO}_{2}$ by $12 \%$ (Figure 5C). In addition, every $10 \mathrm{~kg} \mathrm{ha}^{-1}$ of calcium increase, when irrigated with non-saline water $\left(0.3 \mathrm{dS} \mathrm{m}^{-1}\right)$ in coated pits, were reduced to liquid photosynthesis (Figure 5B) and the carboxylation efficiency (Figure 5D) in $1.2 \%$. In the other combinations, no functional relationship was observed between calcium doses and liquid carbon dioxide assimilation.
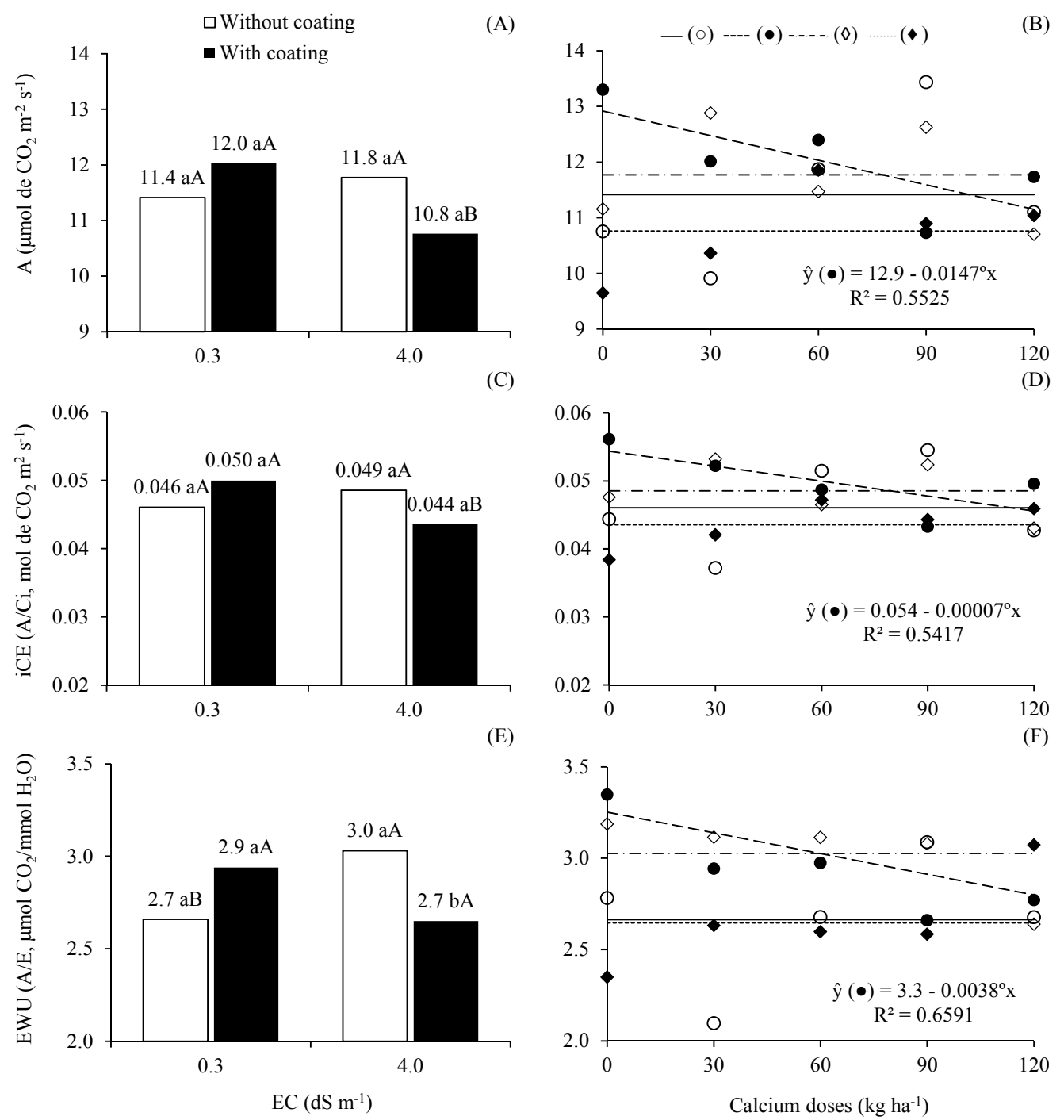

Figure 5. Liquid assimilation of carbon dioxide (A and B), instantaneous carboxylation efficiency (C and D), water use efficiency ( $\mathrm{E}$ and $\mathrm{F}$ ) of leaves of yellow passion fruit (Passiflora edulis) in full bloom, regarding the interaction between lateral coating of the pit and water salinity as a function of calcium doses in the treatments without $(\circ)$ and with $(\bullet)$ coating under irrigation water from $0.3 \mathrm{dS} \mathrm{m}^{-1}$ and without $(\diamond)$ and with $(\diamond)$ coating under irrigation water from $4.0 \mathrm{dS} \mathrm{m}^{-1}$. Averages followed by the same letter, lowercase between pit coating and upper case between electrical conductivity of irrigation water, were not significantly different $(F$ test; $p \leq 0.05)$. ${ }^{\circ}$ and $*$ : significant at 10 and $5 \%$ probability, respectively

Reduced photosynthesis in passion fruit, caused by water salinity, has also been observed by Nunes et al. (2017), in full bloom, and by Freire et al. (2014), at the end of the productive phase. However, the moist root environment, caused by the coating pit (Cavalcante et al., 2005), intensified the decline in the assimilation of 
carbon dioxide because, in this situation, higher absorption of the soil solution and consequently sodium and chloride (Ayers \& Westcot, 1999). Increased sodium levels may cause physiological and biochemical changes in plants. In the present case, as there was no effect of salinity on the quantum kinetics of chlorophyll ' $\mathrm{a}$ ' and on stomatal limitation, the effect of salinity on passion fruit was related to $\mathrm{CO}_{2}$ assimilation. Salinity negatively interferes with biochemical reactions in the stroma of the chloroplasts (Cruz et al., 2017), e.g. increasing oxygenase activity while reducing the carboxylase activity of Rubisco (Sivakumar et al., 2000).

In water use efficiency, under irrigation with water of $0.3 \mathrm{dS} \mathrm{m}^{-1}$, lateral pit coating had no effect. However, under irrigation with water of $4.0 \mathrm{dS} \mathrm{m}^{-1}$, not coating the pits resulted in water use efficiency increase by $11 \%$ (Figure 5E), while pit coating combined with irrigation with saline water $\left(4.0 \mathrm{dS} \mathrm{m}^{-1}\right)$, reduced the efficiency of plant water use by $10 \%$. In addition, increasing calcium doses to $10 \mathrm{~kg} \mathrm{ha}^{-1}$, while irrigating with non-saline water $\left(0.3 \mathrm{dS} \mathrm{m}^{-1}\right)$ and coating the pits, resulted in a decreased water use efficiency by $1.3 \%$ (Figure $5 \mathrm{~F}$ ).

As the effect of salinity of irrigation water on passion fruit leaf transpiration was not significant, the reduction in water use efficiency (Figure 5E) is most likely related to the decreased photosynthesis (Figure 5A). Similar results have been found by Freire et al. (2014), who stated that a salinity increase of 0.5 to $4.5 \mathrm{dS} \mathrm{m}^{-1} \mathrm{did}$ not interfere with transpiration, but resulted in reduced water use efficiency. However, increased calcium doses may have increased calcium solubility in the coated pits, possibly causing an imbalance in the relationship between calcium and magnesium.

In this study, the interaction between water salinity, coating of the pits, and calcium doses was significant $(\mathrm{F}=$ 7.66; $\mathrm{p}<0.0001)$. The reduction in fruit production caused by lateral pit coating and irrigation with saline water was, on average, 15 and $21 \%$, respectively; when incorporating the costs, the reduction was $4.8 \mathrm{~kg}$ per plant (33\%) (Figure 6A). In terms of fruit production, the responses to the calcium doses were related to pit coating and water salinity (Figure 6B). Using non-saline water and not coating of the pits, there was no functional relationship between calcium and production, while in the treatments with coated pits, fruit production increased only by $0.5 \mathrm{~kg}$ per plant with an increased calcium does of $10 \mathrm{~kg} \mathrm{ha}^{-1}$. With saline water, a functional relationship was established only for plants cultivated in non-coated pits, with production increases from 9.9 to $14.4 \mathrm{~kg}$ per plant $(45 \%)$ at a calcium dose of $59 \mathrm{~kg} \mathrm{ha}^{-1}$.
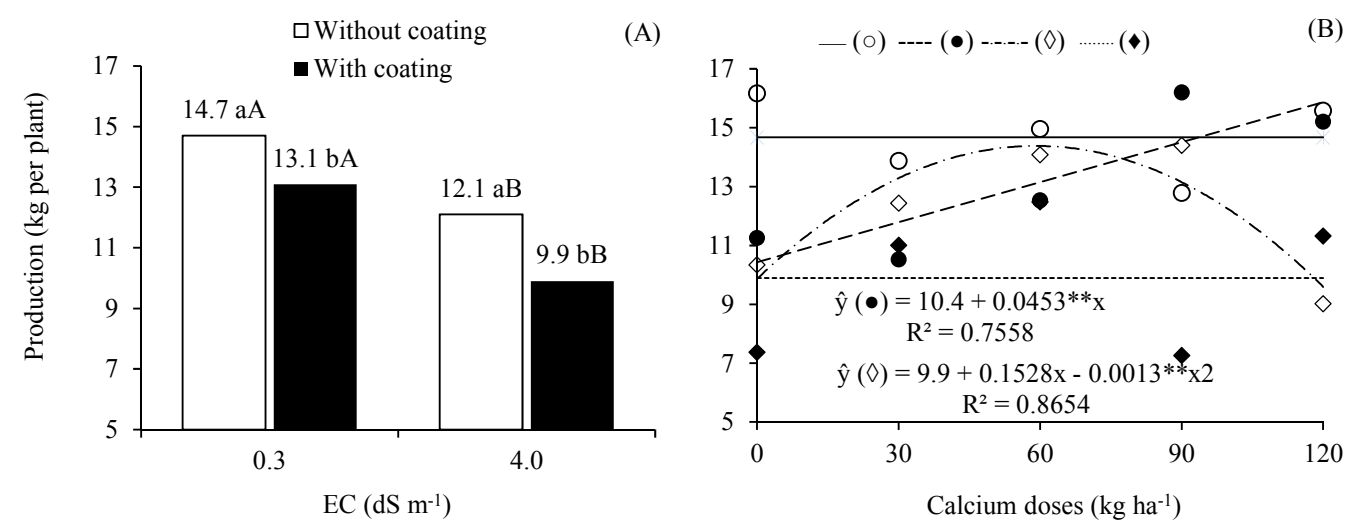

Figure 6. Yellow passion fruit (Passiflora edulis) production in relation to the interaction between lateral pit coating and water salinity (A) and as a function of calcium doses (B) in the treatments without (O) and with $(\bullet)$ pit coating under irrigation water from $0.3 \mathrm{dS} \mathrm{m}^{-1}$ and in pits without $(\diamond)$ and with $(\diamond)$ coating under irrigation water from $4.0 \mathrm{dS} \mathrm{m}^{-1}$. Averages followed by the same letter, lowercase between pit coating and upper case between electrical conductivity of irrigation water, were not significantly different ( $F$ test; $p \leq 0.05$ ). $* *$ : significant at $1 \%$ probability

As noted by Dias, Cavalcante, Nunes, Freire, and Nascimento (2012), an increase in the electrical conductivity of irrigation water of 0.5 to $1.5 \mathrm{dS} \mathrm{m}^{-1}$ reduced passion fruit yield by $19 \%$, while at a salinity of $3.5 \mathrm{dS} \mathrm{m}^{-1}$, yields were reduced by $40 \%$. The decrease observed in this study (45\%) with the use of water of $4.0 \mathrm{dS} \mathrm{m}^{-1}$ reflects the sensitivity of passion fruit to saline water (Ayers \& Westcot, 1999), with implications in physiology (Freire et al., 2014; Nunes et al., 2017). Lateral pit coating, even with the potential to maintain soil moisture and dilute the effects of salts (Cavalcante et al., 2005), was not effective in mitigating stress because, most likely, the moist root environment favored the absorption of the soil solution and, consequently, of salts. Calcium mitigates 
excess salt levels (Fageria et al., 2011) as it competes with sodium and, as observed in this study, stimulates the synthesis of chlorophyll (Figure 1), thereby increasing quantum efficiency (Figure 2) and production (Figure 6B).

\section{Conclusions}

Entisol cultivated with passion fruit should not be irrigated with saline water of $4.0 \mathrm{dS} \mathrm{m}^{-1}$ because of the reduction in photosynthesis and subsequent fruit production. Lateral pit coating, especially under irrigation with saline water, is not an effective measure in passion fruit cultivation. In an Entisol with an initial calcium level of $1.92 \mathrm{cmol}_{\mathrm{c}} \mathrm{dm}^{-3}$, the recommended application dose is $60 \mathrm{~kg} \mathrm{ha}^{-1}$. Calcium fertilization can be used to mitigate the negative effects of highly saline water in passion fruit production.

\section{References}

Alla, M. M. N., Abogadallah, G. M., Badran, E. G., Nada, R. M., \& Hassan, N. M. (2014). Supplementary CaCl $\mathrm{Cl}_{2}$ ameliorates wheat tolerance to NaCl. Acta Physiol Plant, 36(8), 2103-2112. https://doi.org/10.1007/s11 738-014-1587-8

Allen, R. G., Pereira, L. S., Raes, D., \& Smith, M. (2006). Evapotranspiracióndel cultivo: Guías para ladeterminación de los requerimentos de agua de los cultivos (Estudio FAO: Riego y Drenaje, 56). Itália: FAO.

Alvares, C. A., Stape, J. L., Sentelhas, P. C., Gonçalves, J. L. de M., \& Sparovek, G. (2013). Köppen’s climate classification map for Brazil. Meteorologische Zeitschrift, 22(6), 711-728. https://doi.org/10.1127/09412948/2013/0507

Ayers, R. S., \& Westcot, D. W. (1999). A qualidade da água na agricultura (2nd ed.). Campina Grande: UFPB.

Baker, N. R. (2008). Chlorophyll fluorescence: A probe of photosynthesis in vivo. Annual Review of Plant Biology, 59(1), 89-113. https://doi.org/10.1146/annurev.arplant.59.032607.092759

Berry, J. A., \& Downton, W. J. S. (1982). Environmental regulation of photosynthesis. In Govindjee (Ed.), Photosynthesis: Development, carbon metabolism, and plant productivity (Vol. II). Cambridge: Academic Press.

Blankenship, R. E. (2014). Molecular mechanismsof photosynthesis (2nd ed.). Chichester: John Wiley \& Sons.

Borges, A. L., \& Souza, L. de S. (2010). Recomendação de calagem e adubação para maracujazeiro (Comunicado Técnico, 141). Cruz das Almas: Embrapa Mandioca e Fruticultura Tropical.

Cavalcante, L. F., Lopes, E., Diniz, A. A., Seabra Filho, G. Q., Dantas, T. A. G., \& Nunes, J. C. (2014). Produção e composição mineral do maracujazeiro amarelo com adubação foliar de cálcio-primeira safra. Revista Agropecuária Técnica, 35(1), 69-80. https://doi.org/10.25066/agrotec.v35i1.10176

Cavalcante, L. F., Dantas, T. A. G., Andrade, R., Sá, J. R., Macêdo, J. P. S., Gondim, S. C., \& Cavalcante, I. H. L. (2005). Resposta do maracujazeiro-amarelo à salinidade da água sob diferentes formas de plantio. Revista Brasileira de Engenharia Agrícola e Ambiental, 9(Suppl.), 314-317.

Cruz, J. L., Coelho Filho, M. A., Coelho, E. F., \& Santos, A. A. dos (2017). Salinity reduces carbon assimilation and the harvest index of cassava plants (Manihot esculenta Crantz). Acta Scientiarum, 39(4), 545-555. https://doi.org/10.4025/actasciagron.v39i4.32952

Dias, T. J., Cavalcante, L. F., Nunes, J. C., Freire, J. L. de O., \& Nascimento, J. A. M. (2012). Qualidade física e produção do maracujá amarelo em solo com biofertilizante irrigado com águas salinas. Semina: Ciências Agrárias, 33(Suppl. 1), 2905-2918. https://doi.org/10.5433/1679-0359.2012v33Sup11p2905

Eisenach, C., \& Angeli, A. (2017). Ion transport at the vacuole during stomatal movements. Plant Physiology, 175(1), 520-530. https://doi.org/10.1104/pp.17.00130

El Habbasha, S. F., \& Ibrahim, F. M. (2015). Calcium: Physiological function, deficiency and absorption. International Journal of ChemTech Research, 8(12), 196-202.

Epstein, E., \& Bloom, A. J. (2006). Nutrição mineral de plantas: principios e perspectivas (2nd ed.). Londrina: Editora Planta.

Fageria, N. K., Gheyi, H. R., \& Moreira, A. (2011). Nutrient bioavailability in salt affected soils. Journal of Plant Nutrition, 34(7), 945-962. https://doi.org/10.1080/01904167.2011.555578

Faleiro, F. G., \& Junqueira, N. T. V. (2016). Maracujá: O produtor pergunta, a Embrapa responde. Brasília: Embrapa. 
Freire, J. L. O., Dias, T. J., Cavalcante, L. F., Fernandes, P. D., \& Lima Neto, A. J. de (2014). Rendimento quântico e trocas gasosas em maracujazeiro amarelo sob salinidade hídrica, biofertilização e cobertura morta. Revista Ciência Agronômica, 45(1), 82-91. https://doi.org/10.1590/S1806-66902014000100011

Furtado, G. F., Pereira, F. H., F., Andrade, E. M. G., Pereira Filho, R. R., \& Silva, S. S. da (2012). Efeito do nitrato de cálcio na redução do estresse salino em melancieira. Revista Verde de Agroecologia e Desenvolvimento Sustentável, 7(3), 33-40.

Garrone, R. F., Campos, A. G. de, Silveira, C. P., \& Lavres Junior, J. (2016). Produção de biomassa, diagnose nutricional e absorção de nitrogênio e cálcio durante crescimento inicial do pinhão-manso. Revista Ciência Agronômica, 47(1), 22-31.

Guo, W., Nazim, H., Liang, Z, \& Yang, D. (2016). Magnesium deficiency in plants: An urgent problem. The Crop Journal, 4(2), 89-91. https://doi.org/10.1016/j.cj.2015.11.003

IBGE (Instituto Brasileiro de Geografia e Estatística). (2017). Produção agrícola municipal: Lavouras permanentes 2016. Rio de Janeiro: Instituto Brasileiro de Geografia e Estatística. Retrieved from https://sidra.ibge.gov.br/tabela/1613

Nunes, J. C., Cavalcante, L. F., Pereira, W. E., Souza, J. T. A., Almeida, D. J. de, Oresca, D., \& Fernandes, P. D. (2017). Gas exchange and productivity of yellow passion fruit irrigated with saline water and fertilized with potassium and biofertilizer. Ciencia e Investigación Agraria, 44(2), 168-193. https://doi.org/10.7764/rcia.v4 $4 \mathrm{i} 2.1742$

Ortega, A. E., \& Malavolta, E. (2012). Los más recientes micronutrientes vegetales. International Plant Nutrition Institute, 7, 16-25.

Padilha, N. S., Silva, C. J. da, Pereira, S. B., Silva, J. A. N. da, Heid, D. M., Bottega, S. P., \& Scalon, S. de P. Q. (2016). Crescimento inicial do pinhão-manso submetido a diferentes regimes hídricos em Latossolo vermelho distrófico. Ciência Florestal, 26(2), 513-521. https://doi.org/10.5902/1980509822752

Reyes, A. J., Álvarez-Herrera, J. G., \& Fernández, J. P. (2013). Papel del calcio en la apertura y el cierre estomático y sus interacciones con solutos compatibles. Revista Colombiana de Ciencias Hortícolas, 7(1), 111-122. https://doi.org/10.17584/rcch.2013v7i1.2040

Roháček, K. (2002). Chlorophyll fluorescence parameters: The definitions, photosynthetic meaning, and mutual relationships. Photosynthetica, 40(1), 13-29. https://doi.org/10.1023/A:1020125719386

Sá, J. M. de, Leitão, E. T. C., Gomes, C. D. L., Rodrigues, M. H. B. S., Sousa, V. F. de O., Santos, G. L. dos, ... Santos, A. da S. (2018). The initial growth of passion fruit plant irrigated with saline water and the application of biostimulants. Journal of Agricultural Science, 10(9), 357-362. https://doi.org/10.5539/ jas.v10n9p357

Salvador, J. T., Carvalho, T. C., \& Lucchesi, L. A. C. (2011). Relações cálcio e magnésio presentes no solo e teores foliares de macronutrientes. Revista Acadêmica: Ciência Animal, 9(1), 27-32. https://doi.org/ 10.7213/cienciaanimal.v9i1.11060

Sivakumar, P., Sharmila, P., \& Saradhi, P. P. (2000). Proline alleviates salt-stress-induced enhancement in Ribulose-1,5-bisphosphate oxygenase activity. Biochemical and Biophysical Research Communications, 279(2), 512-515. https://doi.org/10.1006/bbrc.2000.4005

Steduto, P., Hsiao, T. C., Fereres, E., \& Raes, D. (2012). Cropyield response towater (Estudio FAO: Riego y Drenaje, 66). Itália: FAO.

Taiz, L., Zeiger, E., Møller, I. M., \& Murphy, A. (2017). Fisiologia e desenvolvimento vegetal (6th ed.). Porto Alegre: Artmed.

\section{Copyrights}

Copyright for this article is retained by the author(s), with first publication rights granted to the journal.

This is an open-access article distributed under the terms and conditions of the Creative Commons Attribution license (http://creativecommons.org/licenses/by/4.0/). 